\title{
OS CAMINHOS DO JUSNATURALISMO NO SÉCULO XXI
}

\author{
Núbia Athenas Santos Arnaud* \\ Paulo Henrique Tavares da Silva**
}

RESUMO: Este ensaio cuida da convivência do jusnaturalismo no cenário cada vez individualista e tecnocrático da pós-modernidade. Para tanto, perpassa pela história do direito natural, objetivando ressaltar as tendências que acompanharam essa abordagem do fenômeno jurídico desde a antiguidade clássica, apontando os motivos de seu gradual declínio após as revoluções burguesas do século XVIII, sucumbindo às correntes do positivismo jurídico, a partir do século XIX. Trata-se de estudo, pois, de natureza prospectiva, construído a partir do método hipotético-dedutivo, que se utiliza da pesquisa documental, com ênfase na doutrina.

Palavras-chave: Jusnaturalismo; Positivismo; Direitos Fundamentais; Hermenêutica; Princípios.

\section{THE PATH OF JUSNATURALISM IN THE 21ST CENTURY}

\begin{abstract}
This essay deals with the coexistence of jusnaturalism in the increasingly individualist and technocratic scenario of postmodernity. To do so, this paper goes through the history of natural law, objectifying the resurgence of its tendencies in attention to this kind of logic, from a classic antiquity, pointing the impulses of its gradual process to the eighteenth century, succumbing to the Legal Positivism School in the 19th century. It is a study, therefore, of a prospective nature, based on the hypothetical-deductive method, which makes use of documentary research, with an emphasis on doctrine.
\end{abstract}

Keywords: Jusnaturalism; Positivism; Fundamental Rights; Hermeneutics; Principles.

\footnotetext{
${ }^{*}$ Mestranda em Direito e Desenvolvimento Sustentável pelo Centro Universitário de João Pessoa - UNIPE, membro do Grupo de Pesquisa Estado, Sociedade Civil e Desenvolvimento Sustentável. arnaud.athenas@gmail.com

** Doutor e Mestre em Direitos Humanos e Desenvolvimento pela UFPB, professor dos cursos de graduação e pós-graduação da UFPB e do UNIPE, membro permanente do PPGD/UNIPE, líder do Grupo de Pesquisa Estado, Sociedade Civil e Desenvolvimento Sustentável. prof.paulohenriquetavares@gmail.com
} 


\section{INTRODUÇÃO}

O jusnaturalismo viu-se revigorado a partir da segunda metade do século XX - após a II Guerra Mundial, frente a necessidade de reincorporar valores antes esquecidos, mas que se mostraram imprescindíveis para a proteção do ser humano em face das arbitrariedades perpetradas por regimes totalitários. À racionalidade em que se radicava o direito natural, desde o final da Idade Média, atrelou-se a necessidade de evocar a justiça, em suas variadas dimensões, como fundamento mesmo dos sistemas jurídicos que nasciam no pós-guerra.

Mesmo a Declaração Universal dos Direitos do Homem (1948) embute aspectos metafísicos a partir da aceitação de elementos decorrentes da razão e que apelam ao senso comum de justiça do gênero humano, componentes que se espraiam nas sucessivas declarações de direitos produzidas pelos organismos transnacionais, destacando-se os pactos pelos direitos políticos, civis e aqueles ligados ao desenvolvimento econômico e social. Em verdade, a concepção transindividual de homem portador de direitos universais serviu de elemento retórico poderoso à penetração dos catálogos de direitos fundamentais nas mais variadas cartas constitucionais dos países centrais e, especialmente, periféricos.

Mas, essencialmente, o que se perquire aqui é se ainda tem cabimento falar-se em jusnaturalismo em sociedades marcadamente impregnadas por um crescente individualismo, estimulado mesmo pelo desenvolvimento das novas formas de arranjos econômicos, bem assim frente à construção de textos legais cada vez mais estritos sob o ângulo da condição humana, restrições que se justificariam pelo apego ao utilitarismo e às condições econômicas da reserva do possível?

A contemporaneidade atrai o debate entre a frieza revelada pela tecnocracia e o antropocentrismo holístico que a dimensão do jusnaturalismo incorpora ao sentido do direito como ferramenta de regulação social. Nesse embate, parte o presente estudo da hipótese de que a disciplina dos valores, dimensão inarredável dos modernos sistemas jurídicos, corrobora ainda para a convivência do direito natural nos ordenamentos jurídicos existentes no século XXI, sendo pauta indispensável quando se fala da interpretação e aplicação desse mesmo direito. Ou seja, é imprescindível o uso da retórica do direito natural, se quisermos praticar a justiça social.

Trata-se de estudo de natureza prospectiva, que utiliza da análise doutrinária e do conteúdo do ordenamento jurídico nacional e internacional, a partir do uso do método hipotético-dedutivo, considerando que radica em cada ordenamento jurídico elementos que 
atraem a retórica do direito natural como ferramenta hermenêutica. Além da evolução histórica do jusnaturalismo, o ensaio projeta a manutenção do uso da concepção racional da condição humana como elemento de modelagem da aplicação do direito a cada caso concreto, especialmente aqueles mais difíceis, onde se estabelece o embate entre princípios constitucionais díspares.

Para tanto, o artigo apresenta particionamento tríplice. Inicia-se com uma breve evolução histórica da ideia do direito natural e das sucessivas migrações em seu sentido, ao tempo que se desenvolviam as concepções de mundo, particularmente na Europa. Em continuidade a tal cenário, cuidaremos de demarcar a ascensão e o declínio do positivismo, com ênfase no normativismo, construindo o cenário ao renascimento do jusnaturalismo, nos anos de 1940. Segue-se a parte final, onde se discutirá a pertinência do pensamento fundado numa racionalidade humana universal, aplicável ao mundo tecnocrático contemporâneo.

Ao fim, busca-se a confirmação da hipótese, asseverando que o século nascente prenuncia o fim da dicotomia entre direito positivo e direito natural, a partir da centralidade da pessoa, elevada à condição de valor universal e potencialmente direcionado à tolerância e articulação com as realidades locais, atuando tanto na fase de feitura das normas mas, especialmente, no processo de interpretação e aplicação das normas jurídicas.

\title{
2 A IDEIA DE DIREITO NATURAL
}

O direito natural ${ }^{1}$ tem seu histórico intimamente ligado ao do desenvolvimento da filosofia do direito, razão pela qual as suas bases teóricas são sistematicamente chamadas para explicar a compreensão do pensamento jurídico acerca do tema em análise. O jusnaturalismo busca demonstrar a existência de uma ordem jurídica imutável, superior, anterior ao próprio homem, acima de todas as prescrições criadas pela cultura humana e que dá fundamento ao direito.

\begin{abstract}
A história da filosofia do direito é, em larga medida, idêntica à história do direito natural. É a história da questão sobre como extrair, a partir de algo indisponível, isto é, a natureza (e um dos maiores problemas é o de saber qual tipo de natureza que deverá estar em causa), critérios e normas para o
\end{abstract}

\footnotetext{
${ }^{1}$ Apesar da proximidade, direito natural e junaturalismo são coisas distintas. O jusnaturalismo é a teoria que explica e fundamenta a existência do direito natural. Porém, a evolução de ambos ocorre conjuntamente, razão pela qual se optou por tratá-los como sinônimos.
} 
comportamento humano, que se revelam resistentes perante o arbítrio humano. Esta é uma pergunta tão actual hoje como há dois mil anos, no tempo das tecnologias nuclear e genética (KAUFMANN, 2015, p. 59-60, grifos no original).

O pensamento jusnaturalista está baseado no verdadeiro, justo e obrigatório, onde a justiça se apresenta como imperativo máximo, ou melhor, no valor a ser perseguido, e que conduz à verdade. O direito natural é o conjunto mínimo de valores, extraídos pela natureza humana inerente a cada homem, bem como pela vontade de Deus e pela força da natureza (HUPFFER, 2011, p. 1).

O direito natural precede o ser humano, porém, precisa ser descoberto, revelado e esse tarefa é possível por meio do uso da razão, uma concepção grega constituída como um dos traços distintivos da raça humana. A razão é o pensar segundo princípios e valores universais, sendo também a aptidão do homem de acumular conhecimento e transmiti-lo através da linguagem, "representa, também, a percepção do outro, do próximo, em sua humanidade e direitos. Idealmente, a razão é o caminho da justiça, o domínio da inteligência sobre os instintos, interesses e paixões" (BARROSO, 2001, p. 13).

A escola do direito natural, ou a teoria do jusnaturalismo, é uma corrente jusfilosófica que sustenta a existência de leis objetivas que espelham uma ordem preestabelecida e na possibilidade de seu descobrimento por meio da razão. Assim, a validade do ordenamento jurídico (ou o seu reconhecimento como um poder, pelos membros da comunidade) é obtida por meio de sua identificação com essa ordem superior objetiva. (SCHIAVON, 2001, p. 358)

É importante destacar a carga axiológica que o direito natural carrega consigo, conforme exposto acima, sendo intrínseco ao jusnaturalismo a existência de valores, deles sendo indissociável, sob pena de descaracterizar a sua formação. Os valores dão o tom a esse pensamento na medida em que baliza suas ideias, sempre voltadas para consecução do justo.

Num primeiro momento, na era arcaica pré-científica (antes do século VII a. C), não havia nenhuma base científica, tudo era explicado através dos mitos (KAUFMANN, 2015, p. 60). O homem explicava os acontecimentos a partir das suas observações sem nenhuma metodologia, prevalecendo o sobrenatural, a fatalidade, as forças místicas. Nesta seara, o direito apenas existia nas sagas e nos contos, aceito sem maiores questionamentos. 
$\mathrm{Na}$ história do jusnaturalismo clássico a peça teatral do pensador grego Sófocles Antígona - é um marco referencial citado por muitos autores. Nela, Antígona desafia Creonte, contrariando suas ordens, sob o pretexto de que as leis ditadas pelos homens não possuem aptidão de revogar as leis naturais ${ }^{2}$, aquelas já promulgadas nas eras imemoriais pelos portavozes dos deuses (HECK, 2008, p. 215).

Nesse momento, é possível perceber a superação do mítico para o racional, a ordem tradicional passou a sofrer críticas, deixando de lado o pensamento cosmológico (explicação através de deuses, fenômenos da natureza, etc) para consolidar uma visão antropológica; na Grécia antiga teve início com os sofistas. O que se buscava com isso era, na verdade, incutir no homem a ideia de moral, o domínio das paixões, levando ao domínio sobre si mesmo, constituindo a verdadeira liberdade (SHIAVON, 2001, p. 363).

Em Roma houve a separação da moral e do direito, com base no que fora desenvolvido pela filosofia grega. Apesar da longevidade do Império Romano, seus homens ocupavam-se mais do direito e da política, permitindo, nesse ponto, influência do pensamento externo, porém, aperfeiçoado com a prática no uso em questões concretas (SHIAVON, 2001, p. 369). Importante frisar que o sistema jurídico da antiguidade mais elaborado foi o romano, inclusive com influência até nos dias atuais.

A Idade Média traz consigo a construção do jusnaturalismo de raiz teológica, haja vista a grande influência religiosa nesta quadra histórica. Não sem razão, viviam-se tempos onde a religião - cristianismo - ditava todas as regras de conduta, e por consequência definia a moral, estabelecendo os limites para o entendimento do que seria o Direito.

O pensamento, via de regra, era voltado para o aspecto divino, relacionando-o com todos os fatos e justificando os acontecimentos, quase um retorno aos mitos da era arcaica, onde, inclusive, os questionamentos não poderiam ser expressos com plena liberdade para não contrariar os dogmas impostos. Contudo, a lei natural não foi refutada, mas recepcionada e analisada sob a concepção de ter sido uma lei revelada no seio da Cristandade.

\footnotetext{
2 "CREONTE: E apesar disso tiveste a audácia de desobedecer a essa determinação? ANTÍGONA: Sim, porque não foi Júpiter que a promulgou; e a Justiça, a deusa que habita com as divindades subterrâneas jamais estabeleceu tal decreto entre os humanos; nem eu creio que teu édito tenha força bastante para conferir a um mortal o poder de infringir as leis divinas, que nunca foram escritas, mas são irrevogáveis; não existem a partir de ontem, ou de hoje; são eternas, sim! e ninguém sabem desde quando vigoram! - Tais decretos eu, que não temo o poder de homem algum, posso violar sem que por isso me venham a punir os deuses! [...]"'(SÓFOCLES, 2005, p. 30-31)
} 
São Tomás de Aquino $^{3}$ buscava conciliar o dogma da fé inserido no Novo Testamento e a Lei Natural a partir das premissas dessa última; ele entendia que o direito natural é uma parte do intelecto humano dado pelo Criador, logo, as verdades reveladas são acessíveis à simples razão. Assim, as ordens divinas existentes na Bíblia são compatíveis com o entendimento da razão humana, pois ambos, no final, possuem a mesma origem divina (HECK, 2008, p. 216).

O legislador da lei natural e o legislador da lei revelada são o mesmo. O Deus cristão legisla tipos de leis com matrizes diferentes. O fato de Deus, como único legislador, estar isento de contradição, ao promulgar a lei criada e a lei revelada, não esclarece se iria se contradizer caso viesse a legislar duas ou mais leis reveladas. Segundo uma doutrina, Deus fez as leis naturais com o mundo que criou e, desde então, respeita que esse funcione de acordo com aquelas, quer dizer, o legislador divino não altera a ordem natural dada pela constituição originária do cosmo. Ao homem cabe ater--se ao ius naturale e, como guardião fiel, rejeitar qualquer violação daquelas leis como ofensivas ao Criador. (HECK, 2008, p. 218).

O tomismo, mais influente sistema filosófico e teológico da época medieval, destacase por estabelecer os limites entre a fé e a razão, estabelecendo ser a lei um ato originário da razão, e não da vontade, classificando-a em quatro espécies: lei eterna, lei natural, lei positiva humana e lei positiva divina (BARROSO, 2001, p. 23).

A decadência de Idade Média trouxe novos pensamentos, principalmente dissociados do aspecto teológico e dos dogmas então estabelecidos, a nova cultura laica deixa de lado o caráter divino para dar lugar à razão humana. O renascimento e depois o iluminismo trouxeram a ciência como base para o novo modo de pensar, e o homem para o centro das ideias.

A nova ordem implantada pelo renascimento cultural e o iluminismo é caracterizada por uma ciência ampliada e aprofundada, onde a razão estava presente não só no aspecto teórico das concepções ora desenvolvidas, mas também na sua atuação prática. Era imprescindível que houvesse um método, até para atribuir caráter científico ao que estava

\footnotetext{
3 “Um dos principais teóricos da lei natural foi Tomás de Aquino. A tese por ele sustentada está em o Direito Natural conter primeiro a lei eterna e, em segundo lugar, a razão humana, que já se apresenta promulgada por Deus" (HUPFFER, 2011, p. 1).
} 
sendo desenvolvido, com o intuito de comprovar a veracidade dos argumentos apresentados, que não estavam mais firmemente associados ao aspecto divino e seus dogmas. Vive-se um momento de ruptura na história.

O jusnaturalismo moderno rompe não só com o medieval, mas também com o clássico quando deixa de lado os fundamentos ontológicos e teológicos para adotar um racionalismo subjetivista e abstrato, as normas não emanam mais de Deus, mas da natureza e esse entendimento é percebido pelo próprio homem através do uso de sua razão (XIMENES, 2011, p. 3).

As especulações são deixadas de lado, o conhecimento - ciência e filosofia - não é buscado pela simples curiosidade e desejo de aprender, mas pela vontade de dominar, não basta apenas sentir.

O direito natural moderno está completamente sujeito ao encanto do conceito científico racionalista, ela é também a sua fonte. A ratio - a ratio humanal - dá ao homem a lei natural. Não há nenhum logos, nem ideias em si mesmas existentes, nem Lex aetrena, não há verdade preestabelecida como na escolástica (em todo caso, ela serve de ponto de partida para argumentação), o homem conta apenas e só com sua capacidade de conhecimento. Autoridade e tradição já não determinam o que seja o direito correcto; só deve vigorar aquilo que faça racionalmente sentido, que seja razoável (direito racionalista). A filosofia do direito libertava-se da teologia, o direito natural era secularizado. (KAUFMANN, 2015, p. 84-85).

Essa mudança de paradigma começou com o Renascimento, séculos XVI e XVII, tendo seu apogeu com o Iluminismo, século XVIII, representando o ideal de que a humanidade sairia de uma era de escuridão para outra de luzes, através do uso da razão. Com o advento do Iluminismo, e sua busca pela razão, conhecimento e liberdade, os entraves ao pensamento e produção intelectual foram superados, deixando para trás o autoritarismo e a superstição vividas na Idade Média, consagrando o novo modelo de vida baseada no homem como centro das coisas, desenvolvimento da ciência, tolerância religiosa, dentre outras expressões da liberdade.

A influência do jusnaturalismo no Iluminismo propunha uma sociedade construída a partir de bases naturais e racionais, sem diferenças entre os homens, onde estes poderiam construir sua felicidade, o que serviu de substrato para a formação das primeiras legislações 
codificadas. Esse também foi o contexto histórico da Revolução Francesa ${ }^{4}$, que consagrou os direitos individuais do homem, a partir da abstenção do Estado em intervir na sua esfera privada. A burguesia emergente precisava sacramentar a igualdade entre todos os homens, pouco importa sua origem, e deveria constar de um documento escrito, positivado.

Também já era chegado o tempo da maturidade para se transformar o direito natural do iluminismo em codificação. O sistema global delineado por Christian Wolff (a ideia de um sistema fechado de todo o conhecimento é característica do racionalismo) aplanou o caminho para os códigos jusnaturalistas dos séculos XVIII e XIX. (KAUFMANN, 2015, p. 92).

Ao contrário do que se possam imaginar, essas codificações não representavam o ápice do direito natural na modernidade, ao, em tese, compilar seus ideais; na verdade, o que pareceu uma evolução representou o fim. Não houve uma busca racional e empírica, levando em consideração as circunstâncias do contexto histórico vivido naquele momento, o que garantiria validade universal para o que estava sendo produzido. Os grandes códigos foram concebidos adotando procedimentos de acordo com a escolástica, extraindo as normas a partir de alguns poucos princípios.

Houve, assim, na verdade, uma projeção do que seria o Direito, a perspectiva de uma coisa racional dentro no contexto iluminista, mas terminou por ceder lugar ao procedimento de outrora, de certo modo idealizando o que se entenderia por justiça.

Nesse ínterim, destaque-se a formação dos Estados Modernos. Para tanto, tornava-se necessário um fundamento que justificasse a sua concepção como algo anterior ao ordenamento jurídico, antecedendo ao que já existe e de onde emanaria toda a estrutura estatal. Aqui há diversas teses para explicar o surgimento dessa nova forma de organização política soberana: Grotius, Hobbes, Rousseau, etc, porém, não cabe traça-las e discuti-las, haja vista o propósito estabelecido não coincidir com essa temática, mas importa deixar registrado esse aspecto do direito natural na modernidade, bem como a sua importância da formação e justificação da atual forma de organização estatal.

\footnotetext{
4 "É a partir desses eventos que a racionalização do Direito ganhou mais força tomando por base a filosofia do iluminismo, por sua estrutura objetiva, formal, tecnicista, que depende de definições claras, objetivas, coercitivas e universais, para proclamar suas "verdades eternas". Como pensamento filosófico, o iluminismo buscou, no "apriorismo" do Direito, a fundamentação de que devem existir normas jurídicas absolutas e universalmente válidas, obrigatórias e imutáveis. Foi desse modo, com efeito, que na doutrina do iluminismo o conceito de mundo jurídico se dissociou do mundo dos fatos, passando a caracterizar o espírito científico dessa época" (HUPFFER, 2011, p. 2).
} 


\section{ASCENSÃO E DECLÍNIO DO POSITIVISMO JURÍDICO}

O direito natural, antecedente a toda humanidade e sua criação cultural, atribui a todo ser humano, independentemente dos elementos exteriores à sua essência, o rol mínimo de direitos em virtude da simples constatação de ser um membro da raça humana. Portanto, essas faculdades garantidas pela própria natureza são de tamanha grandeza que não podem sequer serem violadas pelo Estado, inclusive no eventual exercício de uma atividade indispensável, ao contrário, existe um espaço onde cada indivíduo poderá exercer suas liberdades sem que haja qualquer interferência na sua busca pela felicidade.

A crença de que o homem possui direitos naturais, vale dizer, um espaço de integridade e de liberdade a ser preservado e respeitado pelo próprio Estado, foi o combustível das revoluções liberais e fundamento das doutrinas políticas de cunho individualista que enfrentaram a monarquia absoluta. (BARROSO, 2001, p. 24, grifos no original).

É nesse contexto que é idealizada a Revolução Francesa, juntamente com a Declaração dos Direitos do Homem e do Cidadão (1789), a Declaração de Independência dos Estados Unidos (1776), e com menos destaque, por ser bem anterior, a Revolução Gloriosa (1689), fazendo surgir o Estado Liberal, bem como o constitucionalismo moderno.

De acordo com o afirmado no item anterior, o jusnaturalismo, a partir da compreensão proclamada pelo Iluminismo, foi o responsável pelo movimento de codificação do direito iniciado no século XIX, destacando-se o Código Civil francês, ou Código de Napoleão. Isto só foi possível diante da postura assumida por essa nova filosofia racional, concreta e centrada, que além de trazer a tolerância religiosa com a ruptura com conhecimento a partir das bases teológicas, permitiu também a impor limites ao poder do Estado.

O propósito do jusnaturalismo, com apoio do Iluminismo, ao compilar os textos era dar clareza, unidade e simplificar ao entendimento dos novos parâmetros após a ascensão da burguesia e o surgimento do Estado Liberal, bem como o novo entendimento racional dado ao Direito Natural.

O advento do Estado liberal, a consolidação dos ideais constitucionais em textos escritos e o êxito do movimento de codificação simbolizaram a vitória 
do direito natural, o seu apogeu. Paradoxalmente, representaram, também, a sua superação histórica. No início do século XIX, os direitos naturais, cultivados e desenvolvidos ao longo de mais de dois milênios, haviam se incorporado de forma generalizada aos ordenamentos positivos. Já não traziam a revolução, mas a conservação. Considerado metafísico e anticientífico, o direito natural é empurrado para a margem da história pela onipotência positivista do século XIX. (BARROSO, 2001, p. 25-26).

O cientificismo e a razão levados ao extremo, tratando toda espécie de conhecimento humano com a menor carga de subjetivismo possível, trouxe essa nova forma de concepção do Direito, fazendo surgir o positivismo. A vontade e a ação humana são absolutamente afastadas, porque se buscava abordar todos os conhecimentos como uma ciência exata, sem variáveis e interferências humanas.

Na verdade, o Direito Natural esteve preocupado em trazer um direito tão racional e científico que acabou por modificar suas próprias bases, dando lugar a uma nova forma de pensamento. "Para muitos autores, o Direito Positivo tem seu fundamento no Direito Natural. Os que defendem essa postura amparam-se na convicção de que o direito Natural oferece os pressupostos filosóficos da construção ontológica do Direito Positivo" (HUPFFER, 2011, p. 4).

O positivismo filosófico foi fruto de uma crença exacerbada no poder do conhecimento científico. Sua importação para o Direito resultou no positivismo jurídico, na pretensão de criar-se uma ciência jurídica, com características análogas às ciências exatas e naturais. A busca de objetividade científica, com ênfase na realidade observável e não na especulação filosófica, apartou o Direito da moral e dos valores transcendentes. Direito é norma, ato emanado do Estado com caráter imperativo e força coativa. A ciência do Direito, como todas as demais, deve fundar-se em juízos de fato, que visam ao conhecimento da realidade, e não em juízos de valor, que representam uma tomada de posição diante da realidade. Não é no âmbito do Direito que se deve travar a discussão acerca de questões como legitimidade e justiça. (BARROSO; BARCELOS, 2003, p. 146). 
A ciência do direito vivia um momento onde as observações sociais não ocupavam um lugar de destaque nas suas avaliações e construção, deixou-se de lado os métodos das ciências sociais para aplicar os das ciências exatas, mesmo se tratando de esferas do conhecimento distintas, apesar de não estanques, porém, com referenciais que não permitiam a absoluta identidade da metodologia do estudo ${ }^{5}$.

Houve um afastamento da dimensão axiológica das leis, o direito se distanciou dos valores, bem como da moral, passando a ser estritamente objetivo. Acreditava-se que a transformação do direito em ciência passaria necessariamente por isolar qualquer tipo de elemento que precisasse da análise subjetiva na composição das leis. A norma passou a ser quase uma fórmula matemática.

Essa ruptura cocorreu num contexto histórico de mudança no modo em que os Estados eram governados. Primeiramente, existia um soberano que, dentre outras atribuições, criava as leis e por ser detentor da "vontade do Estado" essas normas eram incontestáveis. A lei era válida apenas por ter origem na figura do possuidor absoluto do poder. Depois esse poder foi limitado, passando a existir a distinção entre a lei em sentido formal e material, o seu conteúdo e a forma, todavia, a validade da lei era aferida apenas pelo seu aspecto formal, não pelo conteúdo. A “positividade”, considerada como direito expresso na norma, passa a ser a essência da lei (KAUFFMANN, 2015, p. 115).

A lei passa a ter seu nascedouro no Estado e não através de uma atividade dirigida pelo soberano, mas por alguém legitimado pelo povo, face a nova compreensão estatal - onde os homens transferem para os governantes essa função, validando, por consequência, a produção legislativa por expressar a vontade do povo. Desta feita, a lei válida é aquele que percorre os trâmites para sua elaboração, estabelecidos pelos representantes do povo, sem perquirir acerca do seu conteúdo, diante do excessivo formalismo e busca pela cientificidade, sem esquecer o afastamento dos valores. Vale mais a forma do que a essência.

O positivismo jurídico foi o pensamento filosófico que dominou o início do século $\mathrm{XX}$. Buscando a cientificidade, trouxe, na verdade, dogmas para o direito, haja vista as leis serem válidas tão somente por obedecerem ao processo legislativo correto, sem nenhuma avaliação criteriosa quanto ao aspecto material do conteúdo que era veiculado.

\footnotetext{
5 “O homem chegara à sua maioridade racional e tudo passara a ser ciência: o único conhecimento válido, a única moral, até mesmo a única religião. O universo conforme divulgado por Galileu, teria uma linguagem matemática, integrando-se a um sistema de leis a serem descobertas, e os métodos válidos nas ciências da natureza deveriam ser estendidos à ciências sociais" (BARROSO, 2001, p. 26)
} 
Nos termos expostos acima, isso aconteceu em razão da busca incessante pela razão, no sentido de obter exatamente as respostas do mundo através da ciência. O homem não aceitava mais explicações baseadas em metafísica ou na teologia, era imprescindível uma base concreta e lógica. Todavia, para muitos ${ }^{6}$, essa nova perspectiva de visualizar o Direito findou permitindo a utilização do próprio ordenamento jurídico para avalizar a prática de diversos crimes contra a humanidade.

O positivismo pretendeu ser uma teoria do Direito, na qual o estudioso assumisse uma atitude cognoscitiva (de conhecimento), fundada em juízos de fato. Mas resultou sendo uma ideologia, movida por juízos de valor, por ter se tornando não apenas um modo de entender o Direito, como também de querer o Direito. (BARROSO, 2001, p. 28).

A ruína do positivismo ocorreu em virtude do seu uso degenerado pelos regimes totalitários baseados em ideologias racistas e/ou nacionalistas, principalmente o nazismo, sem esquecer o fascismo e tantos outros em menor escala pelo mundo. Com a separação do elemento valorativo, o Direito se tornou vulnerável à ação daqueles que apenas buscam a legitimação dos seus atos. Neste contexto, considerando que apenas bastava a previsão legal, com um arcabouço estatal capaz de produzir a maior sorte de leis sem o menor conteúdo ético e moral, estava desenhado o cenário perfeito para a maior violação de direitos que se tem notícia na história da humanidade.

Foi o horror vivido na II Guerra Mundial o responsável por colocar em xeque o positivismo jurídico como pensamento jusfilosófico dominante na primeira metade do século XX. Depois das revelações do ultraje à dignidade humana, inspirou-se uma série de reflexões entre os considerados vitoriosos, inclusive com a incorporação da dignidade humana ${ }^{7}$ aos seus

\footnotetext{
${ }^{6}$ Há doutrinadores que não atribuem à estrita obediência à lei como o principal elemento para o declínio do positivismo, porque "uma lei só pode levantar uma problema de justiça, quando, em virtude do seu conteúdo, esteja apta a programar de um certo modo o segundo nível de decisão, isto é, quando ela contiver conteúdo decisório [...] Não se deve com isto supor que o renascimento da discussão acerca do direito natural tenha sido motivado pelas leis injustas de ditadura nazi. É duvidoso que os desenvolvimentos políticos negativos no nazismo tenham sido condicionados ou até somente propiciados pela doutrina do positivismo legalista, ainda que tal haja sido afirmado em muitos artigos no âmbito da discussão sobre o direito natural. O Terceiro Reich não era um Estado legal, tendo os seus crimes sido, majoritariamente, violações da lei. É óbvio que a lei também foi utilizada como instrumento da perseguição a determinados grupos, mas, num estádio mais avançado, tudo isto foi ultrapassado por um plano de destruição ilegal". (ELLSCHEID, 2015, p. 214-215).

7 Sem Auschwitz talvez a dignidade da pessoa humana não fosse, ainda, princípio matriz do direito contemporâneo. Mas tendo o homem produzido o holocausto não havia como ele deixar de produzir os anticorpos jurídicos contra a praga da degradação da pessoa por outras que podem destrui-la ao chegar ao poder.
} 
projetos políticos de reconstrução social e proteção do homem, com vistas a coibir qualquer possibilidade de reincidência. Como resposta a todos esses acontecimentos, era imprescindível refazer toda a ordem jurídica vigente, pois acreditava-se que o direito existente teria chancelado tais absurdos, na medida em que os atos praticados naquela época estavam tutelados pelo ordenamento jurídico válido dentro do Estado.

Importa ter em mente o pós-II Guerra como o surgimento de novos parâmetros para o direito, em virtude seu grande afastamento da moral e a tentativa de corrigir isso. $\mathrm{O}$ desrespeito perpetrado foi tão grande que era impossível continuar vivendo as mesmas regras disciplinadoras de tempos tão sombrios para toda humanidade.

Como consequência desse momento histórico, houve a necessidade de resgatar o valor intrínseco que todo homem carrega dentro si, interente à sua essência, apenas pela simples qualidade de ter nascido como exemplar da espécie humana ${ }^{8}$. O homem é dotado de moral, razão, discernimento, configurando uma afronta ser subjulgado por seus pares, transformando-o em coisa, era preciso resgatar a dimensão valorativa da lei, dando-lhe nova configuração para ter força de superar e recomeçar com um novo referencial para os ordenamentos. Nesse momento, houve a retomada do jusnaturalismo, por derivar da sua essência, sem sequer a necessidade de perquirir sua garantia dentro do ordenamento jurídico ao qual o indivíduo está inserido, porque são valores não outorgados pelo Estado, mas inerentes ao homem. O novo Estado, com a mudança de parâmetro, bem como elevando o valor dignidade, passa a existir em função da pessoa humana, não mais o contrário da forma como vinha sendo conduzido preteritamente. O sentido, a finalidade e o exercício da atividade estatal só possuem legitimidade se estiverem em conformidade com o novo fundamento de validade. O Estado "passa a servir como instrumento para garantia e promoção da dignidade das pessoas individual e coletivamente consideradas." (SARLET, 2012, p.80).

\section{OS CAMINHOS DO JUSNATURALISMO NO SÉCULO XXI}

Como não se pode eliminar o Poder da sociedade política, havia de se erigir em fim do Direito e no Direito o homem com o seu direito fundamental à vida digna, limitando-se, desta forma, o exercício do Poder, que exercício tanto cria quanto destrói. (ROCHA, 2016, p. 52).

8 “A entronização do princípio da dignidade da pessoa humana nos sistemas constitucionais positivos com o sentido em que agora ele é concebido, é, pois, recente e tem como fundamentos a integridade e a inviolabilidade da pessoa humana pensada em sua dimensão superior e para além da existência apenas de um ser dotado de físico. A fonte fática desta opção é a reação contra inaceitáveis excessos da ideologia nazista, que cunhou o raciocínio de categorias diferenciadas de homens, com direitos e condições absolutamente distintas [...]". (ROCHA, 2016, p. 53). 
Ultrapassado o contexto histórico da II Guerra Mundial e perante a necessidade imperiosa de mudança nos paradigmas da formação do Direito, o jusnaturalismo ressurgiu como o resgate dos valores essenciais do ser humano. Achava-se que sob sua tutela não seria mais possível acontecer novamente todas as barbáries incontáveis experimentadas amargamente pelos homens daquele momento histórico, acreditando na cooperação do positivismo para o deslinde indesejado.

Dentre essa nova ideia, surgiu o movimento do neoconstitucionalismo numa tentativa de reaproximação entre a ética e o Direito, onde os principais valores compartilhados pela comunidade são veiculados através dos princípios, seja implícita ou explicitamente citados nos ordenamentos jurídicos. "Os princípios, como se percebe, vêm de longe e desempenham papéis variados. O que há de singular na dogmática jurídica da quadra histórica atual é o reconhecimento de sua normatividade.” (BARROSO, 2001, p. 31).

Além da superação do legalismo estrito experimentado no positivismo, a outra grande mudança ocorrida é a migração da Constituição para o centro do ordenamento jurídico não apenas formalmente; essa novidade traz consigo a pessoa humana como referencial, valor supremo e fim em si mesmo, o Estado possui a ter obrigação de protegê-la e promove-la.

O novo direito positivado é compreendido sempre através dos valores que agora fazem parte do seu contexto normativo, seja no próprio texto de lei, seja por intermédio da interpretação conforme os princípios fundadores do ordenamento jurídico, onde é exigida estrita obediência aos seus preceitos. Importante destacar que esses valores são reconhecidos por todos, são fundamentais para todo sistema jurídico.

Várias propostas surgiram com a finalidade de traçar e explicar a recente concepção que estava surgindo para o jusnaturalismo na contemporaneidade, isto consiste em afirmar o trabalho de grandes filósofos nesta tarefa, com as mais diversas compreensões, todavia, discorrer sobre todos é um trabalho que foge dos limites do presente trabalho, valendo a importância do registro?.

A lei injusta existia, era válida e aplicada sem questionamentos; o jusnaturalismo veio para mudar essa orientação, deixando o Direito menos ríspido e consequentemente mais humano, aproximando-o novamente da moral e da ética. Kaufmann (2015, p. 128) destaca que

\footnotetext{
${ }^{9}$ Para maiores detalhes acerca do assunto consultar: ELLSCHEID, Günter. O Problema do Direito Natural: uma orientação sistemática. In A. Kaufmann; W. Hassemer. Introdução à Filosofia do Direito e à Teoria do Direito Contemporâneas. 2. ed. Fundação Calouste Gulbenkian. p. 211-280; e KAUFMANN, Arthur. A problemática da Filosofia do Direito ao Longo Da História. In A. Kaufmann; W. Hassemer. Introdução à Filosofia do Direito e à Teoria do Direito Contemporâneas. 2. ed. Fundação Calouste Gulbenkian. p. 57-161
} 
"a tarefa que nos é dada é a limitação da arbitrariedade na legislação e na aplicação da lei; está em causa a descoberta de elemento indisponível no direito", todavia, o autor pondera que é inútil imaginar uma forma de pensar em um Direito pós-II Guerra onde haja separação absoluta do positivismo e jusnaturalismo, ao contrário, ambos devem estar juntos nessa construção.

O direito natural é apresentado como alternativa para os horrores vividos durante o conflito bélico mundial, na verdade era uma reação às atrocidades realizadas sob o manto da lei. O neoconstitucionalismo foi fruto dessa resposta, buscava-se a melhor Constituição ${ }^{10}$ possível, justificada numa ordem superior.

Calha aqui apontar o conceito de direito cunhado por Gustav Radbruch, como "uma realidade cujo sentido é o de estar a serviço de valores", somente encontra esse desiderato se servir ao valor jurídica, a ideia de direito, e esta, não pode ser outra senão a justiça (2010, p. 47). Apesar dessa diretiva, interessante ainda notarmos a observação de Luis Recásens Siches, a situar os princípios do jusnaturalismo como elementos de indispensável consideração na fase de produção das normas, isto é, as normas positivas derivariam da inspiração valorativa que adviria do direito natural (1997, p. 43). Entretanto, a práxis jurídica está a sinalizar demanda diversa, impondo a observância a valores universalmente reconhecidos, a partir da construção dos direitos humanos com uma base racional compartilhada pelo gênero humano.

Desde que não exista questionamentos sobre a absoluta validade dos princípios considerados absolutos pelo jusnaturalismo, ele poderá ser considerado como elemento argumentativo na fase de interpretação e aplicação do direito positivo. Apenas é preciso averiguar o quão forte e socialmente aceito é o argumento colocado em análise. Isto porque as sociedades contemporâneas cada vez mais fundam-se numa aparente autonomia do sujeito, este portador de direitos subjetivos cada vez mais particularizados e isolados do interesse coletivo.

Essa teoria que finca a essencialidade do direito nos valores culturalmente aceitos representa o ponto de contato extremo entre o juspositivismo e o jusnaturalismo, no exercício constante de acertamento da dimensão interpretativa dada aos princípios consagrados em cada ordenamento jurídico. Um argumento poderá ser forte e ao mesmo tempo possuir grande aceitação na sociedade, então sua efetividade e aplicação será maior. A título de exemplo é

\footnotetext{
${ }^{10}$ Foi considerado o direito natural como transversal a qualquer estrutura do processo de conhecimento do direito, dirigindo-se a todas as pessoas e forças políticas, auto-imposto, sem questionar a quem competiria a sua descoberta (ELLSCHEID, 2015, p. 219-220).
} 
possível mencionar a dignidade humana como um argumento/princípio do direito natural utilizado para dar nova interpretação ao ordenamento jurídico: todos os dispositivos legais deverão ser interpretados de modo onde o ser humano não seja um meio, um objeto, mas um fim em si mesmo, constituindo-se dever de todos indistintamente o respeito à sua condição de ser humano, sem a necessidade de qualquer justificativa, apenas pelo seu nascimento.

Todo o edifício jurídico, na modernidade, em relação aqueles países que se dizem civilizados, adotam como eixo dogmático o primado da dignidade da pessoa humana. É um valor representativo e diretivo dos sistemas normativos, elevado à condição de universalmente aceito. Por ele, são canalizadas as mais diversas demandas sociais, que se relativizam quando tratamos de temas locais, de demandas específicas, de casos concretos. Isso porque ele é uma resultante de um feixe de temas que intercruzam. A dignidade da pessoa humana, como valor universal, apresenta as três características da universalidade apontadas por Joseph Raz: as condições de sua aplicação podem ser postuladas sem o uso a referências particulares, tais como tempo ou espaço, ligadas a algum indivíduo em especial; pode ser invocado em qualquer lugar e tempo e, por fim, é possível que cada indivíduo possa manifestá-lo em sua inteireza (2004, p. 51-53).

Portanto, percebe-se a estrita ligação entre o jusnaturalismo e o positivismo na atual quadra histórica, sem exclusão de qualquer deles, na tentativa de harmonizar os ordenamentos jurídicos com a tutela dos valores e das pessoas. Não é possível esquecer o fato da estrita legalidade também consagrar benefícios ao cidadão, como por exemplo, vinculação das autoridades ao expresso em lei, impedindo privilégios. Agora, essa garantia contra arbitrariedades foi qualificada pelo elemento do direito natural, pois existe a certeza de que há princípios morais e éticos que também irão orientar a atuação estatal.

É como se o positivismo ganhasse um predicado que o qualifica. Continua existindo a necessidade de produção de lei em sentido formal para a construção do Direito, todavia, conforme a ordem superior de regras que preexistem ao próprio homem e por isso não podem ser derrogadas pela sua simples vontade. O racional/científico se uniu ao ético/moral em favor da ideia de justiça. 


\section{CONCLUSÃO}

O jusnaturalismo passou por diversas mudanças ao longo dos anos, bem como assumiu uma variedade conteúdos acompanhando as alterações no comportamento e entendimento vivenciados em cada trecho distinto da linha cronológica do tempo, chegando aos dias de hoje carregando uma elaboração densa e complexa.

Mas o principal ponto para compreensão é perceber que o direito natural deixou de ser algo baseado apenas na vontade divina para se tornar uma lei ditada pela razão. "A ênfase na natureza e na razão humanas, e não mais na origem divina é um dos marcos da Idade Moderna e base de uma nova cultura laica, consolidada a partir do século XVII". (BARROSO, 2001, p. 23).

Apesar das divergências iniciais existentes entre o jusnaturalismo e o positivismo, baseadas principalmente no conflito entre subjetividade $\mathrm{x}$ objetividade, conteúdo $\mathrm{x}$ forma, valor x racionalidade, a evolução do pensamento mostrou o encontro de pontos em comum, culminando com a formação do direito vigente atualmente, formando-se condições para uma ambiência participativa, na qual o jusnaturalismo atua no processo de formação da norma e, na fase de sua concretização, arejando o sistema a partir da constante dos valores universais encartados no ordenamento jurídico.

A união de forças teve sua origem no combate às atrocidades do nacional-socialismo durante a II Guerra Mundial, onde "o direito foi pervertido até se tornar irreconhecível" (KAUFMANN, 2015, p. 125), acreditando-se que no momento imediatamente posterior ao término do confronto deveria haver um retorno ao direito natural, reconstruindo tudo do zero, porque era impossível viver num Estado com leis tão injustas.

Superando a dicotomia anterior, o jusnaturalismo é chamado para impor limites com a reinserção do elemento valorativo nos textos legais, juntamente com uma nova forma de interpretar o ordenamento baseado em princípios (mandamentos de forte carga axiológica), mesmo quando eles não possuam previsão expressa nos textos legais. "A tarefa que nos é dada é a limitação da arbitrariedade na legislação e na aplicação da lei”. (KAUFMANN, 2015, p. 128).

Vive-se um tempo onde o jusnaturalismo serve de argumento para a proteção de direitos indisponíveis do ser humano, o conteúdo mínimo interente a cada pessoa em virtude tão somente do seu nascimento, o núcleo intangível pelo Estado ou por outro semelhante, protegendo-os contra qualquer forma possível de arbitrariedade. A forma de implementação 
varia de acordo com o pensamento adotado, todavia, é consenso que os ordenamentos são abertos na realização das suas interpretações, não há rol exaustivo de possibilidades e nem limitações, importa apenas a maior efetividade possível do conjunto normativo da dignidade da pessoa humana (valor supremo dos ordenamentos jurídicos atuais).

\section{REFERÊNCIAS}

ANTUNES ROCHA, Carmem Lúcia. O PRINCÍPIO DA DIGNIDADE DA PESSOA HUMANA E A EXCLUSÃO SOCIAL. Revista do Instituto Brasileiro de Direitos Humanos, [S.1.], n. 2, p. 49-67, maio 2016. ISSN 1677-1419. Disponível em: <http://revista.ibdh.org.br/index.php/ibdh/article/view/29>. Acesso em: 17 jul. 2018.

BARROSO, Luís Roberto. Fundamentos Teóricos e Filosóficos do Novo Direito Constitucional Brasileiro. Pós-modernidade, teoria, crítica e pós-positivismo. Revista Direito Administrativo. v. 225, p. 5-37, jul./set. 2001. Disponível em: < http://bibliotecadigital.fgv.br/ojs/index.php/rda/article/download/47562/44776> Acesso em 01 de ago. 2018.

BARROSO, Luís Roberto; BARCELlOS, Ana Paula de. O Começo da História. A nova interpretação constitucional e o papel dos princípios no direito brasileiro. Revista Direito Administrativo. v. 232, p. 141-176, abr./jun. 2003. Disponível em: < http://bibliotecadigital.fgv.br/ojs/index.php/rda/article/viewFile/45690/45068 >. Acessado em: 05 de ago. 2018.

ELLSCHEID, Günter. O Problema do Direito Natural: uma orientação sistemática. In A. Kaufmann; W. Hassemer. Introdução à Filosofia do Direito e à Teoria do Direito Contemporâneas. 2. ed. Fundação Calouste Gulbenkian. 2015 p. 211-280.

HECK, José N. Origens e Aporias do Jusnaturalismo Moderno. etic@, Florianópolis. v. 7, n. 2, p. 215-232, dez/2008. Disponível em: < https://periodicos.ufsc.br/index.php/ethic/article/view/1677-2954.2008v7n2p215>. Acessado em: 18 jul. 2018.

HUPFFER, Halde Maria. O legado do jusnaturalismo moderno-iluminista para à positivação do direito. In: Âmbito Jurídico, Rio Grande, XIV, n. 89, jun 2011. Disponível em: < http://www.ambito-

juridico.com.br/site/index.php?n_link=revista_artigos_leitura\&artigo_id=9694>. Acesso em 18 jul. 2018.

KAUFMANN, Arthur. A problemática da Filosofia do Direito ao Longo Da História. In A. Kaufmann; W. Hassemer. Introdução à Filosofia do Direito e à Teoria do Direito Contemporâneas. 2. ed. Fundação Calouste Gulbenkian. p. 57-161.

RADBRUCH, Gustav. Filosofia do Direito. São Paulo: Martins Fontes, 2010. 
RAZ, Joseph. Valor, respeito e apego. São Paulo: Martins Fontes, 2004.

SCHIAVON, Giovanne Henrique Bressan. O jusnaturalismo clássico. Scientia Iuris, v. 5, 2001, p. 357-373. $\quad$ Disponível em http://www.uel.br/revistas/uel/index.php/iuris/article/viewFile/11193/9949>. Acesso em $01 \mathrm{de}$ ago. 2018.

SARLET, Ingo Wolfgang. Dignidade da Pessoa Humana e Direitos Fundamentais na Constituição Federal de 1988. 9. ed. Porto Alegre: Livraria do Advogado, 2012.

SICHES, Luis Recásens. Introducción al Estudio del Derecho. 12ed. México: Porrúa, 1997.

SÓFOCLES. Antígona. [S.I]: eBooks Brasil, 2005. Tradução: J. B. de Mello e Souza. Disponível em : < http://www.ebooksbrasil.org/adobeebook/antigone.pdf>. Acesso em: 01 de ago. de 2018.

XIMENES, Julia Maurmann. Reflexões sobre o Jusnaturalismo e o Direito Contemporâneo. Cadernos de Direito. v.1. n.1, 2011. Disponível em: https://www.metodista.br/revistas/revistas-unimep/index.php/cd/article/view/885/412> Acesso em: 10 ago. 2018 